\title{
Change of Title: Bloods Becomes Hemato
}

\author{
Peter Roth
}

MDPI, St. Alban-Anlage 66, CH-4052 Basel, Switzerland; roth@mdpi.com

Received: 22 September 2020; Accepted: 23 September 2020; Published: 23 September 2020

Since January 2020, when the journal Bloods-the International Open Access Journal of Hematology - was founded, we have published six papers. After careful discussion, in order to distinguish our journal from other current publications, and also to benefit our journal's development in the long term, we have decided to change the journal title to Hemato and move the six published papers there. We apologize for any inconvenience this may cause.

This new journal aims to improve the study of clinical and basic research of blood-related diseases. It covers topics related to hematopathology from laboratory to clinical studies and the prevention, diagnosis, and therapeutics of hematological diseases, including components such as blood cells, blood proteins, blood vessels, bone marrow, coagulation. Furthermore, it encompasses topics related to all blood diseases, such as blood cancers, bleeding disorders, and hemophilia. Please find a more detailed description of the contents in the Aims \& Scope in the Journal Menu on the homepage of Hemato. This journal is going to publish four issues per year.

MDPI is based in Basel, Switzerland and is active around the world. MDPI is not only a pioneer, it is currently the largest Science, Technology, and Medical (STM) Open Access Publisher in the world, with a constant and consistently increasing quantity of new submissions from authors all over the world. It is our mission to serve the research community with a reliable, efficient, and simple workflow all conducted in compliance with international Good Practice Codes. Our services and products are backed by memberships with the main stakeholders in the Publisher's Community, including the UN Global Compact which supports corporate sustainability, and we have committed ourselves to the 10 principles associated with the Compact.

Thank you for your interest in Hemato. To publish your work under the nonrestrictive CC: BY 4.0 license for immediate dissemination around the world, please contact us.

Welcome and explore our features!

Conflicts of Interest: The author is employed by MDPI.

(C) 2020 by the author. Licensee MDPI, Basel, Switzerland. This article is an open access article distributed under the terms and conditions of the Creative Commons Attribution (CC BY) license (http://creativecommons.org/licenses/by/4.0/). 